\title{
Determination of the Sensitivity of Cyanobacteria to Rare Earth Elements La and Ce
}

\author{
Ekaterina Koval $^{1 *}$, Anna Olkova ${ }^{2}$ \\ ${ }^{1}$ Agrotechnological Institute of the State Agrarian University of the Northern Trans-Urals, \\ Respubliki Str. 7, Tyumen region, Tyumen, 625003, Russia \\ ${ }^{2}$ Vyatka State University, Moskovskaya Str. 36, Kirov, 610001, Kirov region, Russia
}

Received: 15 April 2021

Accepted: 25 June 2021

\begin{abstract}
The present study determined the species of cyanobacteria (CB) that are the most sensitive to the pollution of the aquatic environment with rare earth elements (REE). CB Nostoc muscorum, Nostoc paludosum, and Nostoc linckia were kept for 24 hours in model solutions with La and Ce concentrations of 0.0001 and $0.001 \mathrm{mg} / \mathrm{L}$ respectively. The titer of the cultures was from $1.2 \cdot 10^{7}$ to $2.7 \cdot 10^{7}$ cells $/ \mathrm{ml}$, the age was 5 weeks, the growth phase was exponential. Next the biochemical responses of $\mathrm{CB}$ were determined: the level of chlorophyll $a$ and the concentration of malondialdehyde (MDA) in the CB homogenate. Nostoc muscorum was practically not exposed to the tested doses of REE. The effects of Nostoc linckia were maximal and most consistent. With La concentration of $0.001 \mathrm{mg} / 1$ the amount of chlorophyll $a$ decreased by 4.2 times compared with the control, while intensity of lipid peroxidation (as estimated by MDA) increased by 2.2 times. These facts taken together indicate severe toxic stress. As a result the range of CB sensitivity to Ce and La pollution is as follows: Nostoc muscorum $>$ Nostoc paludosum > Nostoc linckia. The obtained results show that even systematically and evolutionarily close biological species can differ significantly in response to toxicants.
\end{abstract}

Keywords: rare earth elements, lanthanum, series, bioassay, cyanobacteria

\section{Introduction}

The massive release of pollutants into the environment, their close contact with living organisms oblige the scientific community to search methods and types of organisms that can detect the level of toxicity of pollutants. From this position, cyanobacteria (CB), which have a high adaptive, bioremediation potential, as

*e-mail: koval.ev@gausz.ru

well as a wide range of areas of biotechnological use are of interest [1-3].

Cyanobacteria are gram-negative photosynthetic nitrogen-fixing organisms, which in natural conditions give stability to ecosystems [4]. It has been shown that, in response to the action of various toxicants in CB cells, functional changes occur at the subcellular and cellular levels $[5,6]$ : changes in the amount of chlorophyll $a$ in cells [7], changes in biochemiluminescence [8] and the activity of lipid peroxidation - an indicator of stress and reaction to environmental pollution [9]. Such a variety of pre-lethal highly sensitive $\mathrm{CB}$ responses makes 
it possible to use them for bioassay purposes as test organisms.

High sensitivity of $\mathrm{CB}$ to the action of $\mathrm{HM}$, organophosphorus pollutants, and pesticides was shown in a number of studies [5, 10]. Currently, many hightech industries use rare earth elements (REE). Such industries and their wastes are sources of REE in the environment [11]. The standards for the content of REE in the components of the environment have not been developed yet [12]; therefore, the search for biological species capable of diagnosing the pollution of aquatic environments with REE is highly relevant.

The purpose of our work was to compare sensitivity of three cyanobacterial species to low doses of lanthanum and cerium.

\section{Material and Methods}

Lanthanum sulfate $\mathrm{La}_{2}\left(\mathrm{SO}_{4}\right)_{3} \cdot 8 \mathrm{H}_{2} \mathrm{O}$ and cerium sulfate $\mathrm{Ce}_{2}\left(\mathrm{SO}_{4}\right)_{3} \cdot 8 \mathrm{H}_{2} \mathrm{O}$ were used to simulate the pollution of the aquatic environment. Salt additives were added to distilled water until the concentrations of active ions reached 0.0001 and $0.001 \mathrm{mg} / \mathrm{l}$. The investigated solutions simulated ultra-low pollution. In this case we were guided by the published data related to the effect of lanthanum sulfate on survival, life span, growth, development, fertility of crustaceans Ceriodaphnia affinis Lilljeborg in the dose range from 0.16 to $3.53 \mathrm{mg} \mathrm{La} / 1$ [13].

Test organisms were Nostoc muscorum Ag., Nostoc paludosum Kütz, and Nostoc linckia (Roth) Born.

a)

\section{[S Chlorophyll $a \bullet$ Malonic dialdehyde}

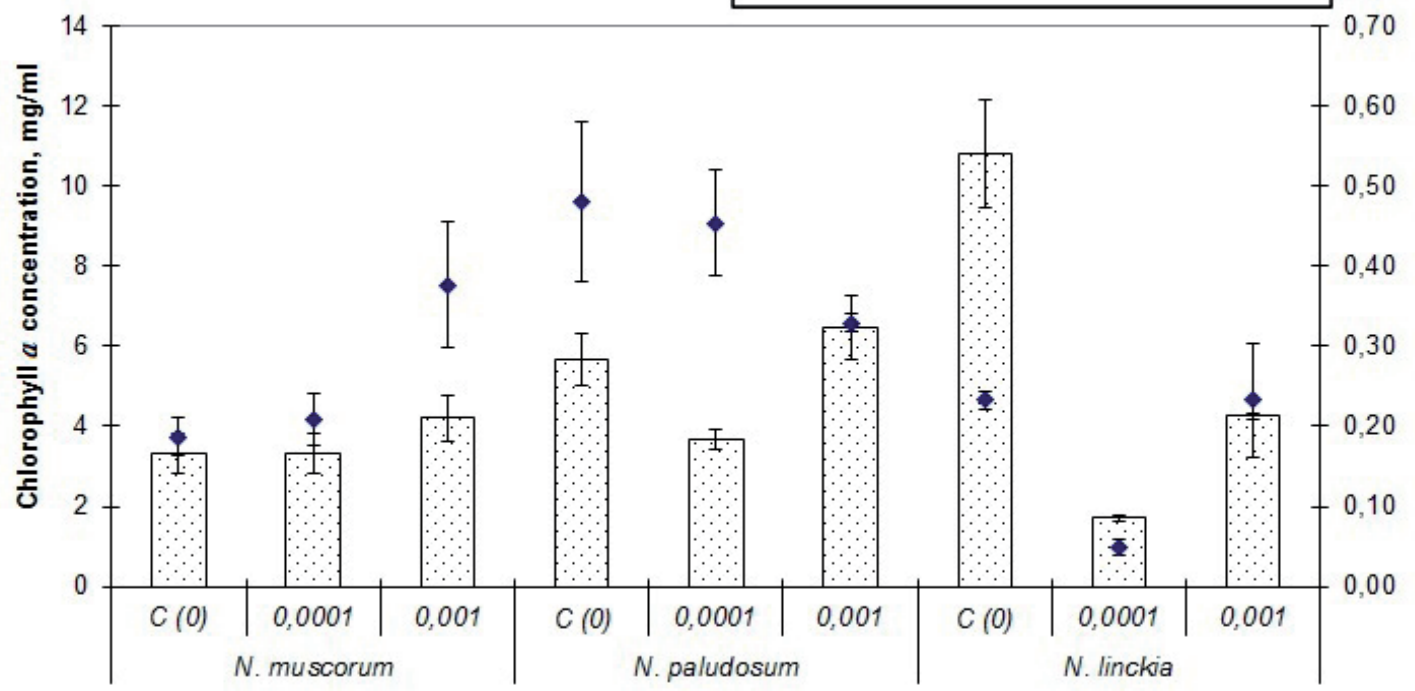

b)

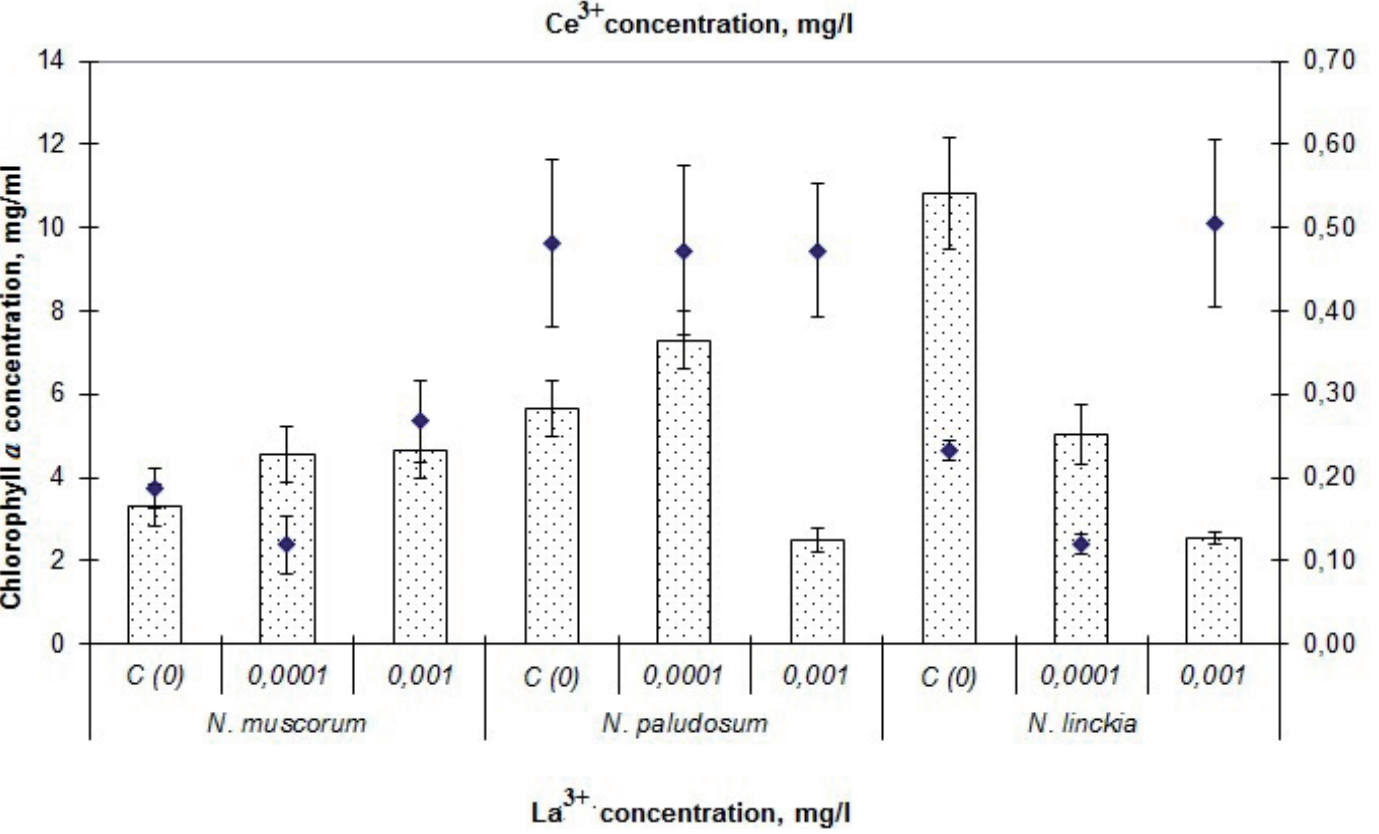

हَ

Fig. 1. Biochemical effects of the action of lanthanum and cerium in various cyanobacteria ( $a$ - the effect of Ce; $b$ - the effect of La). 
et Flah. Algologically pure cultures of $\mathrm{CB}$, which were grown under constant illumination (3000 lx) and temperature $\left(+25^{\circ} \mathrm{C}\right)$ on Gromov liquid medium №6 without nitrogen, were used. Microorganisms were used in the exponential growth phase, which was determined by cell titer by direct counting in the Goryaev chamber: N. linckia $-1,7 \cdot 10^{7}$ cells $/ \mathrm{ml}$, N. paludosum - $1,2 \cdot 10^{7}$ cells $/ \mathrm{ml}, \quad N$. muscorum $-2,7 \cdot 10^{7}$ cells $/ \mathrm{ml}[14]$, culture age -5 weeks.

For bioassay purposes the $\mathrm{CB}$ culture was homogenized, then placed in solutions of toxicants for 24 hours. The toxicity of the model solutions was assessed by changes in the biochemical parameters of $\mathrm{CB}$ : the content of chlorophyll $a$ and the intensity of lipid peroxidation (LPO) processes. The chlorophyll $a$ content was determined in the $\mathrm{CB}$ homogenate by the spectrophotometric method with the use of the device Specol 1300 (Germany) [15]. The intensity of LPO processes was analyzed by the color reaction of thiobarbituric acid with malondialdehyde (MDA), the main product of lipid oxidation processes. The method of spectrophotometric determination of the intensity of LPO processes in plant tissues [16], which we adapted for work with $\mathrm{CB}$, was taken as a basis.

\section{Results and Discussion}

The Fig. $1(a, b)$ shows the biochemical responses of $\mathrm{CB}$ to the presence of $\mathrm{La}$ and $\mathrm{Ce}$.

Cyanobacterium $N$. muscorum proved to be resistant to contamination of the test medium with lanthanum and cerium salts with their additions equal to 0.0001 and $0.001 \mathrm{mg} / 1$ (calculated on active ions). The differences in chlorophyll $a$ concentration from the control data were unreliable $(p>0.05)$. The tendency to accumulate MDA in cells against the background of a stable level of chlorophyll $a$ indicates that the culture of $N$. muscorum is under stress $[17,18]$, but at the same time, the antioxidant system of CB is likely to actively suppress the destructive effect of free radicals and inhibit oxidative processes [19, 20]. However, our aim was to find out the $\mathrm{CB}$ type sensitive to low doses of REE pollution.

The reaction of $N$. paludosum test organisms to REE was more pronounced, but not always consistent. In experiments with cerium salt additives, a lower dose of the substance $(0.0001 \mathrm{mg} / \mathrm{L})$ led to a decrease in the concentration of chlorophyll $a(\mathrm{p}<0.05)$ by 1.5 times compared to the control, and the response to the increased dose was at the level of control values ( $\mathrm{p}>0.05$ ). Lanthanum influenced more strongly, its addition equal to $0.001 \mathrm{mg} / \mathrm{l}$ led to a decrease in the concentration of chlorophyll $a$ in $N$. paludosum cells by 2.3 times compared to the control $(\mathrm{p}<0.05)$. There were no significant differences in the MDA concentration in the variants of the experiment with lanthanum. This fact may indicate that low doses of REE act as essential microelements, which insert into natural metabolic processes, possibly as antioxidant coenzymes and contribute to inhibition of intensity of oxidative stress $[21,22]$.

The cyanobacterium $N$. linckia was found to be the most sensitive to low doses of $\mathrm{La}$ and Ce. The level of chlorophyll $a$ in all experimental variants was significantly lower than in the control variants $(p<0.05)$. In experiments with cerium salt additives, the reaction to a lower dose of the toxicant was more pronounced than to an increased dose $(0.001 \mathrm{mg} / \mathrm{l})$, which manifested in a decrease in the content of chlorophyll $a$ by 6.3 times compared to the control level. Such paradoxical effects are often found when studying the action of low doses of substances [23]. The response of $N$. linckia to water pollution with lanthanum sulfate showed significant distress. A decrease in the concentration of chlorophyll $a$ by 2.2 and 4.2 times was when exposed to 0.0001 and 0.001 $\mathrm{mg} / 1 \mathrm{La}^{3+}$ respectively. At an increased concentration of lanthanum $(0.001 \mathrm{mg} / \mathrm{l})$, we simultaneously recorded a sharp increase in the concentration of MDA in the cells of the CB. A decrease in the content of chlorophyll $a$ may be a consequence of activation of oxidative processes, during which degradation of chlorophyll molecules occurs, as well as inactivation of enzymes of pigment biosynthesis.

The obtained data are consistent with the results of our earlier studies. CB N. linckia was more sensitive to the action of Lignohumate, which is a humic preparation with a high content of humic acid salts used in agriculture [24]. However N. linckia is most resistant to the action of phosphorus-containing toxicants (methylphosphonic acid and the herbicide Glyphosate) compared to $N$. muscorum and $N$. paludosum. In addition, CB N. linckia is sensitive to the action of some HM. For example, copper manifests a decrease in biochemiluminescence and viability by 40 times in activation of catalase formation [5].

\section{Conclusions}

This study showed that the cyanobacterium $N$. linckia has an increased sensitivity to pollution of aquatic environments with rare earth metals (Ce and $\mathrm{La}$ ) compared to Nostoc muscorum and Nostoc paludosum. The value of using $N$. linckia as a test organism consists in reactions to low doses of pollution -0.0001 and $0.001 \mathrm{mg} / 1$, calculated for $\mathrm{Ce}^{3+}$ and $\mathrm{La}^{3+}$ ions.

In general, the obtained data demonstrate that systematically close organisms can differ from each other in their sensitivity to toxicants. Reactions to chemical factors were formed in each species specifically, in accordance with its trophic characteristics, biorhythms, place in the ecosystem, and many other ecologically and evolutionarily significant parameters. From the biochemical point of view, the reasons for interspecies differences in susceptibility to toxicants are most often related to 
the peculiarities in the structures of proteins and the content of fat in the body $[25,26]$. Our results and the indicated data confirm the need to choose the most sensitive test organisms, including those systematically and evolutionarily alike.

\section{Acknowledgments}

The authors are grateful to the Department of Plant Biology, selection and seed breeding, microbiology named after E.A. Shtina VSATU (Russia, Kirov) for the provided cultures of cyanobacteria.

\section{Conflict of Interest}

The authors declare no conflict of interest.

\section{References}

1. VONSHAK A. Spirulina platensis (Arthrospira): physiology, cell-biology, and biotechnology; Editor A. Vonshak, Taylor \& Francis Ltd: London, UK, pp. 252, 2002

2. KLANCHUI A., CHEEVADHANARAK S., PROMMEENATE P., MEECHAI A. Exploring Components of the $\mathrm{CO}_{2}$-Concentrating mechanism in alkaliphilic cyanobacteria Through Genome-Based analysis. Computational and Structural Biotechnology Journal, 15, 340, 2017.

3. DITTMANN, E., GUGGER M., SIVONEN K., FEWER D.P. Natural product biosynthetic diversity and comparative genomics of the cyanobacteria. Trends Microbiol., 23 (10), 642, 2015.

4. CHAKDAR H., JADHAV S.D., DHAR D.W., PABBI S. Potential application of blue green algae. J. Scientific and Industrial Research, 71, 13, 2012.

5. FOKINA A.I., OGORODNIKOVA S.YU., DOMRACHEVA L.I., LYALINA E.I., GORNOSTAEVA E.A., ASHIKHMINA T.YA., KONDAKOVA L.V. Cyanobacteria as Test Organisms and Biosorbents. Eurasian Soil Science, 50 (1), 70, 2017.

6. KOVAL E. V. Influence of cyanobacteria on the vital activity of barley in conditions of contamination with methylphosphonic acid, State Agrarian University of the Northern Trans-Urals: Tyumen, Russia, 147, 2019 [In Russian].

7. CASTENHOLZ R. W. General Characteristics of the Cyanobacteria. Bergey's Manual of Systematics of Archaea and Bacteria, Bergey's Manual Trust: Athens, USA, 23, 2015.

8. SCHEERER ST. Microbial biodeterioration of outdoor stone monuments. Assessment methods and control strategies. The thesis Submitted for the degree of Doctor of Philosophy (PhD), Cardiff University: Cardiff, UK, 256, 2008.

9. BARYLA A., LABORDE C., MONTILLET J.-L., TRIANTAPHYLIDES A., CHAGVARDIE P. Evaluation of lipid peroxidation as a toxicity bioassay for plants exposed to copper // Environmental Pollution, 109, 131, 2000.
10. KONYSHEVA E.N., KOROTCHENKO I.S. Influence of heavy metals and their detoxicants on enzymatic activity of soil. Vestn. Krasn. Gos. Agrar. Univ., 1, 114, 2011.

11. DANG D.H., ZHANG Z.R. Hazardous motherboards: Changes in metal contamination related to the evolution of electronic technologies. Environmental pollution, 268 (B), 115731, 2020.

12. ITOH A., YAIDA A., ZHU Y. Potential Anthropogenic Pollution of High-technology Metals with a Focus on Rare Earth Elements in Environmental Water. Analytical sciences, 37 (1), 131, 2021.

13. LOZHKINA R.A., TOMILINA I.I. The effect of lanthanum on biological parameters of crustaceans Ceriodaphnia affinis lilljeborg in chronic experiments. Toxicological Review, 1, 42, 2016 [In Russian].

14. MUNTYAN M.S., MOROZOV D.A., KLISHIN S.S., KHITRIN N.V., KOLOMIJTSEVA G.YA. Evaluation of the electrical potential on the membrane of the extremely alkaliphilic bacterium Thioalkalivibrio. Biochemistry, 77 (8), 1113, 2012.

15. AMINOT A., REY F. Standard procedure for the determination of chlorophyll $a$ by spectroscopic methods. ICES Techniqnes in Marine Environmental Sciences: Denmark, Copengagen, 25, 2000.

16. LUKATKIN A.S. Cold damage to heat-loving plants and oxidative stress, Publishing house of Mordov. University: Saransk, Russia, 208, 2002 [In Russian].

17. VERONESI C., RICKANER M., FOURNIER J., POUENAT M.-L., ESQUERRE-TUGAYE M.-T. Lipoxygenase gene expression in the Tobacco-Phytophtora parasitica nicotianae interaction. Plant Physiol., 112, 997, 1996.

18. EL-BELTAGI H.S., MOHAMED H.I. Reactive Oxygen Species, Lipid Peroxidation and Antioxidative Defense Mechanism. Notulae Botanicae Horti Agrobotanici ClujNapoca, 41 (1), 44, 2013.

19. MITTLER R. Oxidative stress, antioxidants and stress tolerance. Trends in Plant Science, 7 (9), 405, 2002.

20. SHAO H.B., CHU L.Y.E., LU Z.H.H, KANG C.M. Primary antioxidant free radical scavenging and redox signaling pathways in higher plant cells. International Journal of Biological Sciences, 4 (1), 8, 2008.

21. Trace Elements. National Research Council (US) Committee on Diet and Health. Diet and Health: Implications for Reducing Chronic Disease Risk, National Academies Press: Washington (DC), USA; 14, 1989.

22. DKHIL M.A., ZRIEQ R., AL-QURAISHY S., ABDEL MONEIM A.E. Selenium nanoparticles attenuate oxidative stress and testicular damage in streptozotocin-induced diabetic rats. Molecules, 21, 1517, 2016.

23. EROFEEVA E.A. Hormesis and paradoxical effects upon exposure to pollutants. Dose-Response, 12 (1), 121, 2014.

24. KOVAL E.V., OGORODNIKOVA S.YU. Study of the influence of cyanobacteria and Lignogumate on the life activity of barley. Agrochemistry, 6, 60, 2021 [In Russian].

25. KUTSENKO S.A. Fundamentals of toxicology. Foliant: St. Petersburg, Russia, 715, 2004.

26. BRINKMANN M., PREUSS T.G., HOLLERT H. Advances in Biochemical Engineering-Biotechnology. In Vitro Environmental Toxicology - Concepts, Application and Assessment; Ed. by G. Reifferscheid, S. Buchinger; 1rd ed.; Cham: Springer International Publishing, Switzerland, 157, 293, 2017. 